\title{
AN INTENTIONALISM HERMENEUTIC STUDY ON THE INTERPRETATION OF EDUCATIONAL INVESTMENT
}

\author{
Pradana Fadllillah Afiza*, Purwanti Lilik, Prihatiningtias Yeney Widya \\ Accounting Department, Faculty of Economic and Business, \\ University of Brawijaya, Indonesia \\ *E-mail: afizapradana.akuntansi@gmail.com
}

\begin{abstract}
This study aims to know and understand the meaning of educational investment by Yayasan Abdi Masyarakat Madani Balikpapan using an intentionalism hermeneutic approach. In this study, this intentionalism hermeneutic approach was intended to understand the interpretation of educational investment in the form of permanent lecturer scholarships based on the cultural and historical contexts covering "texts" to know the intention or purpose of the informants. This study conducted in-depth interviews with five informants who are the boards of Yayasan Abdi Masyarakat Madani (YAMM-Bpn) and STIE MADANI (Institute of Economic Science MADANI) of Balikpapan in relation to the scholarship program. From the results, it was found some interpretations of educational investment, defining: educational investment as the fulfillment of a rice plate; educational investment as a means to fulfill the need of selfesteem; educational investment as a means to create a moral duty. This study is expected to give a new perspective to the academic community of accounting in understanding the profits derived from the investment. This research also confirms that the profits of educational investment expected by its investors are not directly materialistic, but rather lead to social improvements, in this term referring to the improvements of education quality in Balikpapan City.
\end{abstract}

\section{KEY WORDS}

Educational investment, intentionalism hermeneutics, educational investment profits, qualitative accounting.

A scholarship is an award or grant provided by the government, private parties or particular institutions to targeted individuals or parties that have met the applicable requirements to ensure their continuity of education they pursue. The scholarship of postgraduate education, both domestically and abroad, seems to be booming in Indonesia. Such a scholarship mostly comes from the government of the Republic of Indonesia. Scholarship providers certainly do not carelessly grant the scholarship funds that much. Instead, the scholarship funds have already been prepared and considered carefully so that those funds can be distributed right on the targets. On another side, behind the grant of the scholarship funds, the scholarship providers definitely intend to gain "profits" (returns) from their programs as well. This kind of scholarship program can be said an investment.

Harbison (1985: 7) discussed the aim and meaning of education itself. According to him, education based on the fulfillment of a State's needs is a philosophy of communist states while education based on the fulfillment of personal needs, desires, wishes, and expectations is a philosophy of liberal states. Pramodyo (2014) affirmed that the philosophies of communist and liberal states are all needed by Indonesia to prepare as best as possible in confronting ASEAN Economic Community (AEC) that has come into force since 2015, integrating all Southeast Asian Countries in various fields, mainly in the economic field, which certainly reinforces the statement saying that educational investment is highly needed in a country

Moreover, Olivia (2017) stated that the high need of educators, especially lecturers, is reasonable because the growth of the number of lecturers is not directly proportional to the increasing need of education in society. Additionally, Billy (2016) revealed that students intend to have a master education because they want professionally to be lecturers. Malang 
is the second largest city after Surabaya City located in East Java, Indonesia. Malang is often referred to as the city of education due to its large number of universities and schools. In total, there are approximately 80 universities in Malang.

Institute of Economic Science Madani of Balikpapan (STIE MADANI of Balikpapan) was established in 1995 under the auspices of Yayasan (foundation) Abdi Masyarakat Madani Balikpapan (hereinafter called YAMM-Bpn). STIE MADANI Balikpapan has been "Accredited B" by the National Accreditation Board with the vision and mission to prepare in short time human resources to be ready to plunge into the working world and to produce independent human resources in anticipating the information system of accounting, including taxation accounting, banking accounting, and computer accounting. YAMM-Bpn tries to seek new prospective lecturers to be placed in the Accounting Department of STIE MADANI of Balikpapan. STIE MADANI of Balikpapan requires permanent lecturers for its Accounting Department because this department still needs many permanent lecturers and dominates the scope of STIE MADANI of Balikpapan. For this effort, YAMM-Bpn intends to allocate scholarship funds to several students who will or are currently studying Master Education of Accounting in several top universities in Indonesia.

Educational investment is related to intellectual investment in terms of value creation. FASB No.6 stated that asset is a possible economic profit gained or controlled by a certain entity as a result of the previous transaction or event. This statement is a reference for a company or organization related to the intellectual investment that is required to fulfill two conditions so that its existence can be recognized as an asset, which is to provide future profits or added values derived from past transactions. If the accounting equation stating that assets include the liability (debt) and equity (capital) of a company or organization is again reviewed, it can be a basis of reference support that the scholarship funds issued by YAMMBpn should be recorded in the asset component, no longer an expense like the conventional accounting system we know today.

The reason for the use of Intentionalism Hermeneutics in this study was that the researchers tried to dig the meaning and interpret investment in the form of texts or words obtained from the informants. Sari (2014) raised the interpretation of profits for the medical profession (doctors) using Intentionalism Hermeneutic interpretation as her study approach. Her study tried to find and disclose the meaning of 'profits' in the doctor's profession. The doctor's profession is closely related to the expensive treatment cost. In addition, Sari (2014) revealed that not all doctors have such a material intention. There are still some doctors who do not put "money" as the embodiment of profits. By having three doctors as the informants, the study successfully discovered four meanings of 'profits' in the profession of doctors, namely profits in the form of savings, profits in the form of spirituality, profits in the form of dignity in the eyes of society and profits in the form of inner satisfaction using Intentionalism Hermeneutic approach. The interpretation results of 'profits' obtained from this research tend to be qualitative and do not prioritize the element of 'profits' in the form of money.

Sari \& Triyuwono (2010) studied the interpretation of profits in educational foundations. They, in their study, tried to seek and reveal the meaning of profits from a different point of view namely educational foundation. A foundation categorized as a non-profit company (not prioritizing profit as its main operational goal) necessarily has no profit in its financial statements. However, as time passed, this study found "profits" in the financial statements made by one of the schools sheltered by the foundation. By using the Intentionalism Hermeneutic method, this research disclosed three meanings of profits, namely material profits, social profits and memorial profits. Material profits are still raised to be one of the interpretation results obtained in the study because there is a possibility that an institution keeps trying to gain profit from its business outcomes although the institution is engaged in the non-profit scope.

In the science of accounting, the researchers found a study discussing murabahah using Intentionalism Hermeneutic approach, which was conducted by Ernawati \& Ludigdo (2012). Murabahah is a general concept of financing organized by banks and other shariabased financial institutions in response to the restlessness of society about usury. In this research, Ernawati \& Ludigdo (2012) had a purpose to understand the meaning of 
murabahah by customers who did murabahah transactions in BMT. The strong reason for the use of Intentionalism Hermeneutic approach in the research was that the researchers could understand the cultural and historical aspects of customers in building their interpretations of murabahah. The results of this research showed that the three informants interpreted murabahah as selling and buying activities with a periodic system of payment that is cheap, easy and social oriented. The historical context was indispensable in the study as a means to know how the customers with their own personal background interpreted murabahah practiced with BMT. On another side, the cultural context of BMT customers was highly necessary for the research because it could be used as a means to know how the customers with their own culture interpreted murabahah practiced with BMT. Sari (2014: 132) explained that these historical and cultural contexts are used by Intentionalism Hermeneutic interpreters to find what the authors (informants)' intentions are contained in texts.

Critical hermeneutics is also used in a study conducted by Aprilianto, Wulandari, \& Kurrohman (2014) analyzing the reality of the use of accounting information by individual stock investors on the Indonesia Stock Exchange by interviewing brokers, entrepreneurs, and students. The results suggested that individual stock investors do not fully utilize accounting information, particularly investors who use technical and non-fundamental analysis. Meanwhile, Friston \& Frith (2015: 129) studied the human communication using Hermeneutics. Their study showed that Hermeneutics is not only used to interpret the texts of ancient books but it also applies in verbal and non-verbal communication.

Based on the above studies, it can be concluded that Hermeneutics is a study to interpret texts. Likewise, Hermeneutics in the field of accounting can also be used to interpret texts in which the texts intended here are something that can be realized in writing, such as profits and nominal realization of educational investment whose existence can be recorded in financial statements. This research aimed to explore the meaning of educational investment made by YAMM-Bpn using Intentionalism Hermeneutic approach. Educational foundations are full of social values. The research on the meaning of educational investment in the educational foundation becomes important because this research provides awareness to the community that the scholarship provided by YAMM-Bpn is a form of human resource investment in which the profits gained by the foundation are not only limited to dwelling on economic reality. Educational investment interpreted using Intentionalism Hermeneutic approach in this research seems to become a unique renewal because educational investment is done to meet the intention and purpose of investors, one of which is to gain profits of the investment.

Theoretically, the results of this research can contribute to the development of financial accounting and capital markets, especially in the theory of Human Capital emphasizing that the current human resources have met the criteria to be recognized as assets (investment) that provide profits (benefits) in the future for a company or organization. Practically, the results of this research can provide an understanding for the community in interpreting educational investment along with its profits obtained by YAMM-Bpn so as to provide awareness to the community that the profits gained from the results of an investment are not only in the form of materials (money) but also other things that can give meaning to the investors.

\section{METHODS OF RESEARCH}

Interpretive Paradigm as Part of Qualitative Approach. This research used a qualitative approach because the object in this research is human, not thing. Kamayati (2016: 44) explained that qualitative research is a research that produces descriptive data in the form of written or oral words of people and their observed behaviors, which often uses qualitative data in the form of interviews, observations, and documentation analyzed by researchers. Moreover, this research used an interpretive paradigm. Interpretive paradigm, according to Chua (1969: 613), derives from the Germanic philosophical interest in which its application tends to the emphasis on language, interpretation, and understanding. This paradigm tries to illustrate that humans are active beings that create their own social reality or world through 
the giving of a meaning system, therefore Sarantakos (1993: 35-36) argued that this paradigm seeks to understand the world through common sense which contains a meaning along with the meaning system used by the community to make sense of the life they live. Also, this paradigm sees knowledge not used to explain and predict, but to understand. Meanwhile, Hoper \& Powell (1985) defined that an interpretive paradigm also assumes that the social reality cannot be separated from the aspirations of the actors and it does occur socially.

Intentionalism Hermeneutics as a Research Approach. Subiyantoro and Triyuwono (2004) described Hermeneutics as a term derived from the Greek word of hermeneuein which means "to interpret". This term has been long known since the $17^{\text {th }}$ century with $\mathrm{F}$. E. D. Schleiermacher as the pioneer. Additionally, Subiyantoro and Triyuwono (2004) explained that Schleiermacher viewed Hermeneutics as a projection of the phenomenon of language and the description of any text using a language with a well-structured discussion. Discussion structures can be used as a means to find the meaning of a sentence. If traced from the perspective of ancient Greek mythology, the word "Hermeneutics" actually comes from the word "Hermes", that is the name of a god who serves as the Messenger of messages to be conveyed from God to mankind. Hermes is a messenger who is often illustrated as a mediator between man and God and assumes the responsibility of interpreting the messages of God from Mount Olympus into a language that human can understand. Hermes must be able to interpret the God's messages into languages that human can understand by knowing well the human language (Butler, 1998; Mulyono, 2012: 15-16).

Initially, hermeneutics is only a means used as an effort to understand ancient Greek literature from which the word of hermeneutics derives, which later developed into a methodology used in the effort to explore and interpret the texts contained in the Gospels. The context of Hermeneutics pioneered by Schleiermacher tends to put forward the universal problems in the form of encountering things that are strange and allow for misunderstanding when we try to understand the thought through words conveyed by informants. Rasmussen (2002) stated that there are several philosophers who developed hermeneutics into a code (rules) of exegesis, such as Friedrich Ernst Daniel Schleiermacher; Hans-Georg Gadamer; Paul Ricoeur; and Jacques Derrida. Meanwhile, Sandage, Cook, Hill, Strawn, \& Reimer (2008) told that in the age of Schleiermacher, hermeneutics was used as an approach to interpreting texts contained in the holy books. Today, hermeneutics is growing rapidly as Schleiermacher broadened his hermeneutical understanding for the formulation of textual interpretations outside the context of scriptures (holy books) such as the texts contained in literature and he extended hermeneutics to penetrate to the interpretation of any kind of texts. Ricoeur (1981) stated that the concept of "texts" becomes widespread because Schleiermacher does not see texts in the form of writing only but also oral speech. Thus, the concept of hermeneutics by Schleiermacher is better known as "Romantic Hermeneutics" or "Intentionalism Hermeneutics".

The researchers decided to use Intentionalism Hermeneutics because this research aimed to interpret the texts derived from the interviews. Intentionalism Hermeneutics more emphasized on the interpretation of texts, in which the texts referred to here are something that can be poured through writing. Interpretation is a method used as an effort of understanding texts, focusing on the understanding of words and languages (Rutt, 2006). Human Resource Investment and its profits are components of accounting science that have a certain meaning or reality, in which accounting can be defined as a business language because it is related to the interpretation arising from stakeholders (Riahi \& Belkaoui, 1980: 363; Hendriksen \& Breda, 1992).

This research was conducted within the scope of YAMM-Bpn located in Kapten P. Tendean Street No. 60 (Gunung Pasir), Balikpapan City, East Kalimantan Province. The selection of informants in research is an important thing because the interview data in the form of voices will be then processed in the form of texts (Sarwono, 2006: 209). The data collection of this research used unstructured interview technique, which was by interviewing 
5 (five) selected informants to obtain information in order to get the results as expected by the researchers.

The function of Hermeneutics is to interpret the meaning and message of a text as objective as possible accordingly with what is intended by the text (Saidi, 2008). Texts are standardized discourses through language. What has been standardized by writing is a discourse that can actually be expressed in the oral form, but the discourse is written because it is not spoken or said. According to Rosyidi (2010: 147), texts are discourses conveyed through writing. The data analysis process in qualitative research is done after the researchers have completed the process of collecting data by interviewing and recording. The researchers acted as the interpreters. The interpreters proxied the "texts" (data) with the information obtained from the informants through the interviews to know the intents or messages of what they conveyed (the authors' intents). Furthermore, the interpreters should look at and explore the historical and cultural contexts contained in the texts. The process of understanding can begin with the interpreter's own questioning about the texts standing in particular historical and cultural contexts which are intended to extract the authors' intents (Bartholomew, 1996: 121). Hess (1993) supports the frame created by Rahardjo suggesting that in understanding a discourse, there are five elements involved in it, including the interpreter, author intent, and texts that have historical and cultural contexts in it.

The historical context was greatly required in this research as a means to know how the informants with their own personal background interpreted educational investment obtained from YAMM-Bpn. Meanwhile, the cultural context was indispensable in this research because it could be used as a means to know how the informants with their own culture interpreted educational investment conducted by YAMM-Bpn. As explained above, Sari (2010: 132) stated that these historical and cultural contexts are used by Intentionalism Hermeneutic interpreters to find what the authors (informants)' intentions are contained in texts. After all the contexts were linked and deepened, the next stage was interpreting the texts to discover the meaning of "educational investment" by the interpreters.

\section{RESULTS OF STUDY}

Dynasty of the Heart of Educational Investment Sympathizers: Overview of Informants. The first informant named Mrs. Kartini. Mrs. Kartini was born and raised in Balikpapan. She inherited the blood of Banjar tribe from her father named Abdul Wahab, S.H. who is the founder of YAMM-Bpn and the pioneer of the Accounting Academy of Balikpapan (Akademi Akuntansi Balikpapan- $A A B$ ) in 1995 in which the status of $A A B$ currently has been raised by Directorate of Higher Education (Dikti) to be STIE MADANI of Balikpapan that we know today. Of her mother, she inherited the blood of Bugis tribe from Makassar. Mrs. Kartini finished her bachelor degree (S1) education in State University of Yogyakarta majoring in linguistics and her master degree (S2) education in the same university majoring in English literary translation. Her educational background that has nothing to do with the world of economics does not lessen the spirit and determination to bring YAMM-Bpn and STIE MADANI of Balikpapan to be better in the future. Mrs. Kartini is one of the initiators of the scholarship program of permanent lecturers for Accounting Department in STIE MADANI of Balikpapan.

The second informant named Mr. Putu. He inherited Balinese blood from his parents. Mr. Putu finished his bachelor degree (S1) education majoring at Economic Teachership in Mulawarman Univesity, Samarinda. In the university, Mr. Putu also completed his master degree (S2) education majoring in Financial Management. He got his Doctorate (Dr.) by completing his doctoral degree (S3) education majoring at Micro in University of Tujuh Belas Agustus, Surabaya. Mr.Putu's educational background that is associated with economics makes him trusted as the chairman of STIE MADANI of Balikpapan.

The third informant was Mr. Dimas, who was born and raised in Jakarta whose bachelor degree (S1) education background is Management in Trisakti University and master degree (S2) education background is also Management in University of Indonesia. Mr. Dimas's educational background that is related to management makes him want to take part 
in advancing education in Balikpapan City by becoming a lecturer in Management Department of STIE MADANI of Balikpapan as well as serving as the Assistant Chief I of Academic Affairs. He inherited Javanese blood from his father and Palembang blood from his mother. Mr. Dimas affirmed that there is no special feature or characteristic of the ancestral culture he follows related to education. He stated that the spirit embedded in himself for his education came from his parents. Hereinafter, Mr. Dimas then decided to contribute in developing the world of education through his statement that education is not merely a means of seeking diploma and academic degree but, more than that, education is self-awareness to gain knowledge (to study).

The fourth informant successfully interviewed by the researchers was the older sister of Mrs. Kartini. She is Mrs. Mardha, a permanent lecturer at STIE MADANI of Balikpapan who also serves as the Assistant Chief II of Administration and Finance Affairs at STIE MADANI of Balikpapan as well as helps Mrs. Kartini in managing YAMM-Bpn operations. Mrs. Marda completed her bachelor degree (S1) education in University of Muhammadiyah Malang and her master degree (S2) education in Gadjah Mada University and Islamic University of Indonesia, Yogyakarta. Currently, she is undergoing her doctoral degree (S3) education in Airlangga University, Surabaya. Mrs. Marda was the first person known by the researchers in the scope of STIE MADANI of Balikpapan. She got involved in this research implementation while teaching and promoting the education of STIE MADANI of Balikpapan.

The last informant interviewed by the researchers was the Assistant Chief III of Student Affairs of STIE MADANI of Balikpapan. He is Mr. Amin. Mr. Amin's bachelor degree (S1) education background is Administration of Mulawarman University while his master degree (S2) education background is Economic Science of Brawijaya University. Currently, Mr. Amin devoted himself as a lecturer in the Department of Management at STIE MADANI of Balikpapan with the academic position as an expert assistant. Mr. Amin was born from his father deriving from Kutai and his mother from Bugis Makassar. He has a family background that cares about education.

The cultural and historical contexts of the five informants above show that the informants have a good history of higher education background, supported by the family circumstances that are also willing to deploy themselves to the world of education. Thus, it can be said that the sense of care of higher education owned by the informants is formed by their own family environments. The informants seemed like a rank of "royal dynasty' which put forward the heart in the struggle for education in Balikpapan City by trying any effort, one of which is by promoting educational investment. For them, education is a bridge to a better life. The various ethnic and cultural backgrounds carried in the blood and bones of the informants suggest that all tribes and cultures in Indonesia have similarities in terms of support for good and beneficial education for mankind.

Should-not-be-Empty Rice Plate: Educational Investment as Fulfillment of Institutional Needs. Rice is the typical staple food of Indonesia whose existence now becomes an "addiction" that is impossible not to be met immediately. Talking about scholarship held by YAMM-Bpn, the researchers then interviewed Mrs. Kartini with more to-the-point questions. Here is the statement conveyed by Mrs. Kartini in response to the question:

"Actually the main goal of this scholarship program is to complete the lacking number of lecturers in our institution. Now then, to realize that goal, we try to adjust it to our vision and mission. As an example, for accounting, our target is to become the best accounting center at least in the scope of Balikpapan. As for what the needs of Accounting Human Resources will be like, that is what we will further check off, like we need a linear accounting workforce and so on. That is what we are looking for".

Mrs. Kartini interpreted educational investment as the fulfillment of the targetted number of permanent lecturers. STIE MADANI of Balikpapan had an unequal ratio between lecturers and students so that such a scholarship program was an alternative means to create full-time lecturers in Accounting Department of STIE MADANI of Balikpapan. Similarly, Mr. Putu gave an explanation as follows:

"As the criteria for the scholarship, the first thing that should be noticed is the academic history. Because, according to the first experience at the beginning of this campus, we also 
ever provided this kind of scholarship to those who were a fresh graduate. Indeed, they did their study here. But they did not come back after they completed their study, whereas the goal of the scholarship program was to get feedback from those who received it. Of course, the devotion should be in accordance with Tridarma (Three Functions) of colleges that starts from the teaching of community services because the college reputation depends on all the inside components, whether or not there is development, not only for the students but also the lecturers".

According to his statement above, Mr. Putu defined educational investment as an investment in a certain period of time, in which "rice" that has been planted must be willing to grow and ready to become "warm rice" for all the academic community of Accounting Department at STIE MADADI of Balikpapan. Meanwhile, Mr. Dimas confirmed Mr.Putu's statement as follows:

"To make an investment in the educational sector, particularly in a campus, it specifically may be difficult for us to find the educators. It is indeed that the Kopertis (Coordination of Private Universities) of the Ministry is directing every campus to invest their students by financing their study to become lecturers at the campus. It can be a reference. The direction indeed leads to it. Mrs. Mardatillah went far to Java just to seek lecturers/ educators. However, at the end of the day, the wisest step is actually to send students to higher education. It could be a reference on how important it is to invest in capital".

Based on his explanation, Mr. Dimas interpreted educational investment as the fulfillment of educators (teaching staff), which was then replied by Mrs. Marda with the following statement:

"As said by my friend, the point is actually like this is our rice plate, so how should we keep our plate full of rice to eat?' That is a very simple philosophy language, is not it? If then I am being asked, so how? Yes, it is clear that we already have the rice plate. But if we want to add meat or eggs, it needs supplements. However, to keep our plate full of rice, at least, there should be rice first. The point is how we keep it. The words 'to keep it' can mean to keep it up or just to keep it remain because the process may still not improve but at least we have to keep it".

The main objective of the scholarship program held by YAMM-Bpn and STIE MADANI of Balikpapan is to meet the number of permanent lecturers at the Accounting Department of STIE MADANI of Balikpapan in accordance with the demand of Directorate of Higher Education as well as to make an equal ratio between the lecturers and students that can lead to ideal teaching and learning activities in the classroom. If "rice" is parable as an essential and urgent staple food, the informants above can be described as individuals who are concerned with the fulfillment of the targetted number of permanent lecturers who want to engage themselves in STIE MADANI of Balikpapan as a basic need, in which the applicable requirements and provisions remain to be the guidelines for its operation.

Fulfillment of the Need of Self-Esteem: Educational Investment as an Effort to Build Institutional Good Name (Reputation). YAMM-Bpn and STIE MADANI of Balikpapan hold the educational investment in the form of scholarship distribution so that the institution can get a good image of the surrounding community, which can increase the interest of the community to undergo lectures at STIE MADANI. Mrs. Kartini as the financial manager of YAMM-Bpn said that STIE MADANI of Balikpapan also provides scholarships to the students who are deemed worthy to receive it. Here is her statement:

"The first aim of the scholarship for our internal students is to promote our institution. Secondly, all private universities indeed have a particular student admission portion for those who have good achievement but less financially capable, and that is why we also provide such a portion".

Mrs. Kartini defined educational investment as a form of social awareness. Although STIE MADANI of Balikpapan is categorized as a young educational institution, its determination and willingness to participate and advance the education sector in Balikpapan City are very big. Furthermore, Mr. Putu replied with the following statement: 
"Actually, this investment will generate profits or benefits in the future, in which the number of students will increase. The increased number of students that is like a sort of spirals that will go up and up will certainly increase the profit as well".

From the above explanation, it is clear that Mr. Putu interpreted educational investment as a means to attract public interest. Similarly, Mr. Dimas confirmed Mr. Putu's statement with the following statement:

"It is not determined by our culture or region, but it tends to the quality of education. We must admit that we are still far behind Java although, yaa sorry to say, if compared to cities in Java region, our city may be more civilized, cleaner because most people here do not throw garbage carelessly, and more disciplined. However, viewed from the education sector, we still hardly meet the targetted quantity, let alone the quality. Above all, with the policy, we hope that all campuses, not only STIE MADANI, can send the native residents of Balikpapan to study in Java, in which after they complete their study, they can come back to Balikpapan and serve as educators to improve the educational quality here. Hopefully, all campuses can implement it".

Through his review, the researchers obtained that Mr. Dimas defined educational investment as a means to improve the quality of education in Balikpapan. This is supported by the statement of Mrs. Marda that:

"Yes, some students may only look for titles or degree, but at least they have to struggle for it. If we as lecturers only concern on titles, why do not our students just buy for it? All is then finished, right? We want our students to fight for their titles. Titles are actually just the bonus. The most important is that the students have to know first why they look for a title? So that they will find and know about their capability, like 'oh yaa my bookkeeping in the office is not well arranged' or etc. They can finally know what mistakes they make".

Mrs. Marda always gives such directions to her students with the intention that the students she teach have a good motivation related to their study at STIE MADANI of Balikpapan in the hope to create the good image and reputation of STIE MADANI of Balikpapan in the eyes of the surrounding community that STIE MADANI of Balikpapan seriously organize the educational program.

Talking about the scholarship organized by STIE MADANI of Balikpapan, Mr. Amin explained that STIE MADANI of Balikpapan opens opportunities for its students to get the scholarships to support the educational process of those who are academically good but less financially capable. Here is his statement:

"We have to always give spirit to make them more improved in the future. Our main vision is indeed to advance education; one of the ways is by providing the scholarship program that provides the students with the ease, facilities, and infrastructure to study in this campus so as to attract others' interest to study here, automatically increasing the education sector".

Mr. Amin interpreted educational investment as a means to obtain a good image from the community as well as to create the campus' attractiveness so as to make STIE MADANI of Balikpapan better known by the public.

Another aim of the scholarship grant by YAMM-Bpn and STIE MADANI of Balikpapan is to increase the "self-esteem" of STIE MADANI of Balikpapan. Of course, a campus that is capable of holding scholarships on a large scale will be able to trigger curiosity as well as good praise from the academic community and the wider community. STIE MADANI of Balikpapan is not half-hearted in prioritizing its vision and mission to advance the education sector in Balikpapan by organizing continuously the scholarship program so that people will surely put their heart and respect to the campus of STIE MADANI Balikpapan, which also can be interpreted as the rise of the campus's self-esteem in the eyes of the wider community.

Creating "Moral Duty" from a Sense of Pride: Educational Investment as a SelfActualization Effort for the Recipient. YAMM-Bpn and STIE MADANI of Balikpapan hope that this scholarship program can create a sense of pride to the recipients influencing on the recipients' totality in carrying out their devotion or dedication to the education sector within the scope of STIE MADANI of Balikpapan in particular and Balikpapan City in general. The 
scholarships are expected to create a sense of desire of the recipients to use all their capabilities to achieve the goal, which we know as "self-actualization".

The recipients of the permanent lecturer scholarships and internal scholarships from YAMM-Bpn and STIE MADANI of Balikpapan have a common goal with the scholarship providers, which is to advance education. Therefore, self-actualization is naturally one of the interpretations of educational investment that is upheld by scholarship providers so as to create symbiotic mutualism conditions with the totality of the recipients' work and dedication as a form of "moral duty" payment coming from a sense of pride in obtaining the scholarship.

Starting from the research question addressed by the researcher to Mr. Dimas in relation to Return of Investment (ROI) obtained by STIE MADANI of Balikpapan from providing scholarships for its permanent lecturers, we have known together that to make a lecturer focus on his work, he should not only contracted with a good salary and facilities but also idealism. It obviously seemed that Mr. Dimas showed enthusiastic facial expression and hand movements as if he would like to persuade the lecturer candidates funded by YAMM$B p n$ to make progress together, devoted to the advancement of education in Balikpapan City. Here is the answer expressed by Mr. Dimas:

"Supposing that you ask on what kind of return will be obtained from the investment, we certainly hope that through the scholarship program contracted with the same vision and mission, the lecturers who receive it can focus on their career. The campus only provides the lecturers with facilities to work while the rest depends on the lecturers themselves. Some of them diligently conduct research while some others eagerly write books. In the end, it will have an effect to the campus because their home base is in the campus. So, the higher the lecturers' career is, the better the campus reputation will be. Compared to other contracted lecturers, the lecturers whose studies we finance certainly have a stronger motivation. Hopefully, their career later can be brighter than any other lecturer".

Mr. Dimas put his hope to the researchers as the recipient of the permanent lecturer scholarship program to become a lecturer who can be relied upon by the campus of STIE MADANI of Balikpapan. The scholarships provided are expected to create a sense of belonging the campus of STIE MADANI of Balikpapan, giving impact on the vision and mission of the campus with the personal vision and mission that aspires to have a more advanced and dignified life in the Eyes of God, society, and nation.

Mrs. Marda confirmed the statement expressed by Mr. Dimas above by explaining that the recruitment process through the scholarship mechanism is to create a sense of satisfaction for its recipients. The satisfaction expected by Mrs. Marda is that the scholarship recipients perceive that becoming a lecturer is indeed their passion so as to make them enthusiastic in their career at STIE MADANI of Balikpapan by holding fast Tridarma of colleges.

However, once again, Mrs. Marda has to face the challenge that she should continuously motivate the existing lecturers to do research and devotion to society, even with forcefulness if needed. With her sullen expression as if she worried about today's profitoriented man, Mrs. Marda gave the following explanation:

"So back again, all lecturers are absolutely able to give a lecture. It is almost impossible if they are not. But, the difficult things for lecturers are to conduct research and devotion. For these two, we often force our lecturers. If any lecturer is not willing to do research and devotion, that is okay but I can make sure that his salary cannot be fixed."

Mrs. Marda stressed that the lecturers in STIE MADANI as the teaching staffs should not just emphasize about what the organization has given to them, they have to more emphasis on what they have given to the organization instead.

Creating "moral duty" of the sense of pride seems to show the other side of scholarships provided by YAMM-Bpn and STIE MADANI of Balikpapan. With the scholarships, it is expected to create a sense of pride in each recipient who directly also can improve their confidence level in the social sphere. The pride is expected to foster the spirit of self-actualization when the scholarship recipients are devoting themselves to the advancement of education at STIE MADANI of Balikpapan in particular and Balikpapan City in general. 


\section{DISCUSSION OF RESULTS}

The purpose of this study was to explore the meaning of educational investment held by YAMM-Bpn using Intentionalism Hermeneutic approach. The keyword of this study is educational investment interpretation. Interpretation can be done by looking at the texts resulted from informants' interviews supported by historical and cultural contexts of each informant to find the author's intention (Bartholomew, 1996: 121). Thus, there are found 3 (three) meanings of educational investment, namely: (1) educational investment as the fulfillment of a rice plate, (2) educational investment as a means of the fulfillment of selfesteem needs, and (3) educational investment as a means to create a moral duty.

As explained in the previous chapter, the existence of permanent lecturers that are willing to be contracted in scholarship programs is an important and urgent basic necessity like a "rice" plate that should not be empty. In relation to the provision of permanent lecturer scholarships, the fulfillment of permanent lecturers for Accounting Department of STIE MADANI of Balikpapan with a number of requirements determined by the Directorate of Higher Education is the main goal of educational investment conducted by YAMM-Bpn. The informants agreed that this could support the fulfillment of permanent lecturers who are contracted to work for 10 years. Thus, the permanent lecturers can be empowered to participate in advancing education at STIE MADANI of Balikpapan by clinging firmly Tridarma of colleges.

The procurement of such scholarship programs also contributes to the students' learning motivation and enthusiasm of STIE MADANI of Balikpapan, by the provision of internal scholarships from YAMM-Bpn and other scholarships from external parties for students who deserve to get it. Therefore, the provision of such scholarships can form qualified human resources and certainly support the vision and mission determined by STIE MADANI of Balikpapan that is to advance education in Balikpapan City.

Besides, the procurement of such scholarship programs absolutely leads to the sense of pride for the recipients as well as attracts public curiosity and interest. An educational institution that totally organizes and provides wide opportunities for its academic community to experience the scholarships certainly will get a positive response from the community.

The realization of qualified human resources in the campus also produces two thumbs up' (good results) from the community as well as creates the image that STIE MADANI of Balikpapan seriously implements education. Of course, it is expected that in the future the community of Balikpapan City, in particular, will pay more attention to education in its own region, especially at STIE MADANI of Balikpapan that the education held in the campus will generate a positive influence on the community around Balikpapan. The increasingly good image of the campus ultimately will also increase public interest to study on the campus, automatically improving the campus's profit in the future.

The scholarship recipients, in this case referring to the permanent lecturer scholarship recipients and the internal scholarship recipients of STIE MADANI of Balikpapan, certainly feel proud of the scholarships they get. The pride is culminating in the sense of belonging and engaging as part of the academic community of STIE MADANI of Balikpapan which has vision and mission to advance education in Balikpapan City.

The sense of having 'moral duty' is expected to become a reference to make the lecturers work totally in their career and to lead the academic community of STIE MADANI of Balikpapan to a better future. Hopefully, the sense of having "moral duty" can encourage the lecturers and students to not just prioritize material things in performing their duties but they have to set targets accordingly with the ideal. Lecturers are educators (teaching staff) of campus or higher education whose main purpose is to run the college Tridarma while students are the ones who are educated by lecturers under campus to explore knowledge, practice their knowledge to the community, and be more aware of social things that require them to get involved.

An institution or organization when dealing with finance must also discuss the accounting side. The accounting discussed in this chapter includes the scholarship budget 
along with the expected "profits" from education investment made by YAMM-Bpn and STIE MADANI of Balikpapan. Talking about the real profit and loss, Mrs. Kartini replied as follows:

"From the beginning, if we talk about the loss in terms of the accounting, well honestly it may be true. However, because the philosophical values we got from our parents are very strong in this foundation, we assume that it is fine if we experience losses now but in $5-10$ years ahead we can make sure that we can already reap the rewards. The losses we get now must have the proportion or size. It is impossible that we always experience losses, isn't? Frankly speaking, supposing we continuously get into losses, automatically we will not be able to finance operations. At least, we always try to set aside some of our funds to finance our operations every month".

Mrs. Kartini seemed to want to pour out her heart that this education investment can also be counted as a "loss" in terms of money. However, Mrs. Kartini interpreted it as profits (benefits) that will be reached in the future because Mrs. Kartini viewed the scholarship as the formation of human capital contributing to the vision and mission of STIE MADANI of Balikpapan that is to advance education in Balikpapan City.

Mrs. Kartini as a highly educated leader understands that investment is an effort to develop the organization she is leading. She realizes that investment is not only materials but can also in the form of the fulfillment of the need of lecturers that can support human resources to create sustainability and progress in YAMM-Bpn and STIE MADANI of Balikpapan for the long term. While pointing to the building in front of the room, Mrs. Kartini conveyed her answer as follows:

"To me, to invest should not only in the form of asset investment. Madani tends to make an investment in buildings, land or other similar things as we know in accounting what these things look like, so we can get the point that Oh yaa we can make an investment not only in the form of materials. In other words, we expense something to get more results. So, what kind of results can we get more? It may be seen or measured but it is not in the form of materials. Instead, it may be power. If reviewed more deeply, in the end, the materials actually will follow. That is all according to me personally".

Mrs. Kartini interpreted educational investment as something that can support the achievement of more results in the future. Moreover, she also interpreted "power" as a profit obtained by STIE MADANI of Balikpapan even though it all requires big cost and sacrifice to get it.

Meanwhile, Mrs. Marda wisely said that YAMM-Bpn as the scholarship funder experiences losses indeed if viewed in terms of money. Here is her explanation:

"If I am being asked, 'do you experience losses and spend a lot of money for making this investment?' Well, financially I think so. But if we conduct more research and devotion so as to make our campus and the facilities become increasingly better, people will then be more interested".

The above statement indicates that the scholarship program, if calculated using the accounting style system, certainly has driven STIE MADANI of Balikpapan to suffer losses due to its money expenditure that is approximately up to hundred million for one scholarship recipient. However, Mrs. Marda thought well of the scholarship investment as an effort to create attractiveness of the campus.

This research is expected to bring positive impacts and implications to the theory, practice, and policy. First, related to the theoretical implication, the results of this research are expected to develop and contribute to human capital theory. The theory confirms that human resources are now recognized as assets, categorized as investments. Human resources expected here refer to permanent lecturers, and the student development is considered as investment owned by YAMM-Bpn and STIE MADANI of Balikpapan because it can generate an increased income in the long term. On the other hand, this research is a research discussing on the field of qualitative accounting so as to provide a new perspective to the further researchers or readers that topics about "investment" can be used as a reference to trigger and continue research with non-positivistic domain so that the world of accounting research becomes richer in discussion subjects. Quite a few researchers know that so far the research on investment in accounting has been concerned about capital 
markets and qualitative management calculations that are considered saturated in the academic community of accounting. The researchers want to give a new nuance to the research topics of "investment" by raising and bringing an interpretive qualitative nuance in it.

Secondly, regarding the practical implication, this research is expected to provide a new perspective to the academic community of accounting in understanding the profits derived from the educational investment. As the research results explain in the previous chapter, the profits of educational investment expected by YAMM-Bpn and STIE MADANI of Balikpapan are not directly materialistic, but rather lead to social improvement, which in this case refer to the quality improvement of education in Balikpapan.

Thirdly, in relation to the policy implication, Mrs. Kartini and Mrs. Mardatillah on behalf of YAMM-Bpn and STIE MADANI of Balikpapan stated that the campus always opens wide opportunities to the postgraduate students of accounting who are or will undergo their study in STIE MADANI of Balikpapan to get the permanent lecturer scholarships along with its work contract for 10 years. Hopefully, this kind of scholarship program is mutually beneficial for both the recipients and YAMM-Bpn as the scholarship providers.

\section{CONCLUSION}

This research aimed to interpret educational investment using intentionalism hermeneutic approach. As discussed in chapter 2, the researchers acted as the interpreters who proxied the "texts" resulted from the in-depth interviews with the informants by looking at the historical and cultural contexts of the informants to know their intentions. The historical and cultural elements could itself explain the "texts" derived from the interviews with the informants about the meaning of educational investment. As the final result, the researchers found 3 (three) interpretations of educational investment, covering (1) educational investment as the fulfillment of a rice plate, (2) educational investment as a means to fulfill the need of self-esteem, and (3) educational investment as a means to create "moral duty". These three interpretations can also be referred to as the 'authors' intention' formulated by Rahardjo (2008: 92) in chapter 2 on page 39.

This research is a qualitative research so that the results of this research cannot be generalized to other research objects. Furthermore, this research had limitations in which the number of informants who were willing to be interviewed by the researchers was only 5 (five) people because they had a bit more involvement with this scholarship program.

For further researchers, to develop this research, we personally suggest them to use semiotics approach presented by Ferdinand de Saussure as a form of renewal to the research methodology so as to research results that are fresh and different from this research. In addition, it is also expected that further researchers can raise and discuss the themes related to accounting such as income, debt, capital, burden, and others to be interpreted using Intentionalism Hermeneutic approach to enrich the study of qualitative accounting.

\section{REFERENCES}

1. Aprilianto, B., Wulandari, N., \& Kurrohman, T. (2014). Perilaku investor saham individual dalam pengambilan keputusan investasi: Studi Hermeneutika-Kritis. e-Journal Ekonomi Bisnis dan Akuntansi, 1, 16-31. https://doi.org/10.19184/ejeba.v1i1.567

2. Bartholomew, C.G. (1996). Three horizons: Hermeneutics from the other end-An evaluation of anthony thiselton's hermeneutic proposals. European Journal of Theology, 121-135.

3. Billy. (2016). 6 daya tarik profesi dosen yang tidak dimiliki profesi lain. Diakses 5 Maret 2018, dari https://www.duniadosen.com/profesi-dosen-g039/

4. Butler, T.O.M. (1998). Towards a hermeneutic method for interpretive research in information systems. Journal of Information Technology, 13, 285-300.

5. Chua, W.F. (1986). Radical developments in accounting thought. The Accounting Review, 61(4), 601-632. 
6. Ernawati, L., \& Ludigdo, U. (2012). Eksplorasi pemaknaan murabahah melalui hermeneutika intensionalisme. Jurnal Akuntansi Multiparadigma, 3(2), 230-241.

7. FASB Summary of Statement No. 142, Goodwill and Intagible Asset.

8. Friston, K.J., \& Frith, C.D. (2015). Active inference, communication and hermeneutics. Cortex, 68, 129-143. http://dx.doi.org/10.1016/j.cortex.2015.03.025

9. Harbison. (1985). Perencanaan pendidikan dan sumber daya manusia. Jakarta: Penerbit Bhratara Karya Aksara.

10. Hendriksen, E.S., \& Breda, M.F.V. (1992). Accounting theory. Boston: Homewood.

11. Hess, R.S. (1993). New horizons in hermeneutics: A review article.

12. Hopper, T., \& Powell, A. (1985). Making sense of research into the organizational and social aspects of management accounting. A review of its underlying asumptions. Journal of Management Studies, 22(5), 429-465.

13. Kamayanti, A. (2016). Metodologi penelitian kualitatif akuntansi (pengantar religiositas keilmuan). Jakarta: Yayasan Rumah Peneleh.

14. Mappalotteng, A.M. (2010). Keuntungan investasi pada berbagai tingkat pendidikan di Sulawesi Selatan. Jurnal MEDTEK, 2(1).

15. Mulyono, E. (2012). Belajar hermeneutika. dari konfigurasi filosofis menuju praksis islamic studies. Yogyakarta: Penerbit IRCiSoD.

16. Olyvia, F. (2017). Dibukanya seleksi CPNS, Indonesia masih kekurangan dosen. Diakses 5 Maret 2018, dari https://www.cnnindonesia.com/gaya-hidup/20170907011857-282240000/dibukanya-seleksi-cpns-indonesia-masih-kekurangan-dosen/

17. Pramudyo, A. (2014). Mempersiapkan sumber daya manusia Indonesia dalam menghadapi Masyarakat Ekonomi ASEAN tahun 2015. Akademi Manajemen Administrasi YPK Yogyakarta JBMA, 2(2).

18. Rahardjo, M. (2007). Hermeneutika gadamerian: Kuasa bahasa dalam wacana politik Gus Dur. Malang: UIN Malang Press.

19. Rahardjo, M. (2008). Dasar-dasar hermeneutika: Antara intensionalisme \& gadamerian. Yogyakarta: Ar-Ruzz Media.

20. Rasmussen, J. (2002). Textual interpretation and complexity - radical hermeneutics. Kopenhagen: The Danish University of Education Department of Educational Sociology.

21. Riahi, A., \& Belkaoui. (1989). The interprofessional linguistic communication of accounting concepts: An experiment in sociolinguistic. Journal of Accounting Research, 18 (2), 362-374.

22. Ricoeur, P. (1981). Hermeneutics and the human sciences: essays on language, action and interpretation. Cambridge, England: Cambridge University Press.

23. Rosyidi. (2013). Analisis teks sastra: Mengungkap makna, estetika, dan ideologi dalam perspektif teori formula, semiotika, hermeneutika dan strukturalisme genetik : (mistisisme cahaya pada puisi "Rumah Cahaya" karya Abdul Wachid B.S.: Kajian metafora dan simbol dalam perspektif hermeneutika paul ricoeur). Yogyakarta: Graha IImu.

24. Rutt, J. (2006). On Hermeneutics. Diakses dari https://e-logos.vse.cz/

25. Saidi, A.I. (2008). Hermeneutika, sebuah cara untuk memahami teks. Jurnal Sosioteknologi, 13. Diakses dari http://journals.itb.ac.id/

26. Sandage, S.J., Cook, K.V., Hill, P.C., Strawn, B.D., \& Reimer, K.S. (2008). Hermeneutics and psychology: A review and a dialectical model. Review of General Psychology, 12, 344-364.

27. Sarantakos, S. (1993). Social Research. Melbourne: Macmillan Education Australia Pty.

28. Sari, D.P. (2014). Apa makna "keuntungan" bagi profesi dokter?. Jurnal Akuntansi Multiparadigma, 5(1), 130-138.

29. Sari, D.P., \& Triyuwono, I. (2010). Tafsir hermeneutika intensionalisme atas "laba" yayasan pendidikan. Jurnal Akuntansi Multiparadigma, 1(3), 489-514.

30. Sarwono, J. (2006). Metode penelitian kuantitatif dan kualitatif. Yogyakarta: Graha Ilmu.

31. STIE Madani Balikpapan. Diakses 5 Maret 2018, dari https://stiemadani.wordpress.com/sejarahnya/

32. Subiyantoro, E.B., \& Triyuwono, I. (2004). Laba humanis, tafsir sosial atas konsep laba dengan pendekatan hermeneutika. Malang: Bayumedia Publishing. 